Goshen. The settlers must have come from Indiana, it would seem. And they kept on coming. When Diagonal was finally set up on the railroad line, the citizens of New Goshen picked up their houses, stores, church, and hitching posts, and moved over to the vicinity of the new station.

More than one town moved, or just died, when a railroad came through a few miles away. Out west of Ames there was an early town, and a pretty one, called New Philadelphia. Now, it's only a few foundation stones in somebody's pasture. The Northwestern went through a half mile north and slowly everything moved over there. The new place was called Ontario - I've never heard why.

A large sign at the edge of the town of Primghar reads, "The Only Primghar in the World." That's probably right. The men on the committee that had to name that town, stirred together the letters of each member's last name, until they came up with Primghar. If that ever happened any place else in the world, it would be interesting to know about it.

\title{
Duncombe and Kenyon Memorials
}

\section{- By Frederic Larrabee}

When Mrs. Mary J. Kenyon, wife of Judge William S. Kenyon, passed away February 22, 1939, in her will she left a bequest of $\$ 20,000.00$ to be used in the construction of two bronze memorial drinking fountains one, a memorial to her father, John F. Duncombe, to be placed in the public square in Fort Dodge, and one, a memorial to her husband, Senator William S. Kenyon, to be located near the court house at Fort Dodge in Webster county.

The memorial to John F. Duncombe is a bronze statue about nine feet three inches in height, resting on a base of North Dakota granite. This statue represents Mr. Duncombe as an attorney when he was 
practicing law in Fort Dodge during the years 1855 to 1902. Mr. Duncombe was an eminent lawyer and was also prominent in Democratic political affairs in Iowa and the nation. This memorial was designed and made by Leonard Crunelle of Chicago, a well known sculptor of this country, who was commissioned to make many memorials placed in various cities in the United States. Mr. Crunelle was for years associated with the famous sculptor Lorado Taft until the death of $\mathrm{Mr}$. Taft, and after that time carried on the work as sculptor completing the unfinished work of Mr. Taft. Although Mr. Duncombe passed away in 1902, many citizens in Fort Dodge have heard much about him and speak of the good reproduction in bronze.

The memorial to Judge William S. Kenyon is located near the Webster county courthouse in Fort Dodge. This is a bronze bust with massive North Dakota granite setting, representing Judge Kenyon as he appeared in court when he was a judge in the United States circuit court. It is a life-like reproduction of Judge Kenyon, and when the weather is pleasant almost any time of the day a group of friends of the judge can be seen looking at the memorial and telling of the admiration they had for Mr. Kenyon when he was practicing law in Fort Dodge, when he was United States senator, and when he was United States circuit judge.

This memorial was designed and made by Albin Polasek of Chicago, a sculptor of international fame. In many cities in this country and Europe are memorials made by Mr. Polasek. 
Copyright of Annals of Iowa is the property of State of Iowa, by \& through the State Historical Society of Iowa and its content may not be copied or emailed to multiple sites or posted to a listserv without the copyright holder's express written permission. However, users may print, download, or email articles for individual use. 